\title{
The Impact of Political Islam on Global IR \& Prospects for Middle East Stability
}

\author{
Ahmed Y. Zohny \\ Coppin State University, Baltimore, USA
}

\begin{abstract}
This work traces the historical development and impact of political Islam on international relations (IR) from the last century to date. In this article the author asserts that understanding the rise of political Islam at the world's stage and IR generally can be genealogically traced to two interrelated developments: the rise of the Muslim Brotherhood (MB) in Egypt since 1928 as a social and political movement against the growing Western influence in the Islamic World after the collapse of the ottoman empire; and the development of the post-World War II IR theories, and practices which provided the basis of the political, military, and security doctrines of the United States and its allies which proved its lack of reliability and validity, particularly as related to the Muslim World, and the role of religion within the Muslim states and place of religion in global politics.
\end{abstract}

Keywords: political Islam, Muslim brotherhood, Egypt, IR theories, Middle East, role of religion in politics

\section{Introduction}

Jeffry Frieden, David Lake, and Kenneth Schultz (2016) argued that emergence of International Relations (IR) started with the Mercantilists era after 1500, where the world as a meaningful political and economic unit only emerged. From this era onward, Henry Kissinger argued that almost as if according to some natural law, in every century there seems to emerge a country with the power, the will, and the intellectual and moral impetus to shape the entire international system and IR in accordance with its own values. In the 17th century, France under Cardinal Richelieu introduced the modern approach to IR, based on the concept of the nation-state and motivated by national interest as its ultimate drive. In the 18th century, Great Britain developed the concept of the balance of power, which dominated IR and European diplomacy for the next 200 years. In the nineteenth century, Metternich's Austria reconstructed the Concert of Europe and Bismarck's Germany dismantled it, reshaping European diplomacy into a cold-blooded game of power politics under Adolph Hitler.

In the twentieth century, no country has influenced IR as decisively and at the same time as inconsistently, as the United States. America's journey through international politics and IR has been a triumph of faith over experience. Since the time America entered the arena of world politics in 1917, it has been so preponderant in strength and so convinced of the rightness of its ideals that the twentieth century's major international agreements have been embodiments of American values - from the League of Nations and the Kellogg-Briand Pact to the United Nations Charter and the Helsinki final Act. The collapse of Soviet communism marked the

Ahmed Y. Zohny, Ph.D., Associate Professor, Chairman, Department of Applied Social \& Political Science, College of Behavioral \& Social Sciences, Coppin State University.

Correspondence concerning this article should be addressed to Ahmed Y. Zohny, Coppin State University 2500 West North Avenue, Baltimore, Maryland 21216. 
intellectual absolution of American ideals and, ironically, brought America face to face with a kind of world it had been seeking to escape throughout its history. What is new about the emerging world order is that, for the first time, the United States can neither withdraw from the world nor dominate it. When America entered the international arena, it was young and forceful and had the power to make the world conform to its vision of IR. By the end of the second World War in 1945, the United States was so powerful (at one point about 35\% of the world's entire economic production was American) that it seemed as if it was destined to shape the world according to its preferences and national interests. But, while the relaxation of U.S.-Soviet tensions with the end of the cold war in 1990 reduced the threat of superpower war, the last decade of the 20th century witnessed the world entering the age of globalization where the world economy became more globalized. And states including the United States and its allies in Europe faced new security challenges embodied in the rise of political Islam as a sub-state security threats and a new actor in international politics and IR.

This research will study the political power of the Moslem Brotherhood (MB)'s - the mother social movement which midwifed political Islam in Egyptian, Arab, Middle East, Islamic geopolitics, and IR generally. The following research questions will guide the analysis: (a) How the power of political Islam has evolved in Egypt; (b) What is the impact of the MB's failure to remain in Power in Egypt on the Middle East's geopolitics, stability and IR generally after the Arab spring; (c) The suitability of the exciting explanatory IR theories to deal with political Islam.

\section{The Rise of Political Islam}

Noah Feldman, in his research on the "Fall and Rise of the Islamic State", argued that "when Empires fall", they tend to stay dead. The same is true of government systems. Monarchy has been in steady decline since the American Revolution, and today it is hard to imagine a resurgence of royalty anywhere in the world. The fall of the Soviet bloc dealt a deathblow to communism; now no one expects Marx to make a comeback. Even China's ruling party is communist only in name. Feldman argued there are however, two prominent examples of governing systems reemerging after they had apparently ceased to exist. One is democracy, a form of government that had some limited success in a small Greek city-state for a couple of hundred years, disappeared, and then was resurrected some two thousand years later. Its re-creators were non-Greeks, living under radically different conditions, for whom democracy was a word handed down in the philosophy book, to be embraced only fitfully and after some serious reinterpretation. The other is Islamic state.

In the 21st century, and on Sunday June 29, 2014, which coincided with the first day of the Muslims holy month of Ramadan, the spokesman of an extremist group battling its way through swaths of Iraq and Syria declared the creation of a formal Islamic State and the restoration of the 7th-century Islamic Caliphate. The legitimate basis of this Islamic state is that the Sykes-Peko agreement which was concluded, following the defeat of the Ottoman Empire and Germany after World War I between England and France resulted in the creation of new states such as Iraq, Syria and Lebanon, Kuwait, Qatar, United Arab Emirates, Oman and Bahrain that it did not exist before, and without the consent or approval of the various ethnic, and minority groups all lived under the Ottoman Caliphate.

The rejuvenation of an Islamic State was the long-declared goal of Hassan al-Banna the founder of the Muslim Brotherhood (MB), the mother organization of political Islam in Egypt in 1928. The move signifies a new era of political Islam's international Jihad, and IR generally. P. J. Vatikiotis in his seminal research, The History of Modern Egypt, From Muhammed Ali to Mubarak, documented the creation of the MB, the only 
militant political organization in Egypt in the 30s and 40s to embrace the theocratic ideal of Islamic government, and to seek by violent and other means to attain it. The MB was different from other Islamic organizations founded during this era such as the Salafiya, and the Young Men's Muslim Association (YMMA) - which was founded as a counterpart to the YMCA, the Society for Islamic Preaching, and Young Egypt — which called for a combination of Muslim faith and action, material sacrifice — and even death—for the sake of a powerful Egyptian empire. But whereas the aforementioned Islamic organizations emphasized the fatherland in terms of king and country with a purification campaign directed against the British occupation, foreign economic and political influence in Egypt, the MB was an Islamic movement of wider scope. It did not confine itself to Egypt. It had followers and local organizations in Syria and Jordan, and maintained close contacts with parallel movements in Iran (Fedaiyan-i-islam), and Pakistan (Jamaat-i-islam). To this extend, the MB had a supra-national or IR dimension and pretention. The realization of power in Egypt meant for the MB the possession of a base for the further extension of its programme and activities in the Arab and Muslim World with the long term goal of the restoration of the Islamic Caliphate.

\section{The Power of Political Islam in Egypt}

While all Muslims share the core belief that there is only one God, and Muhammad was his messenger, the Sunni and Shia sects differ especially on the question of succession following the death of Muhammed. Although the majority Sunnis chose Abu Baker, Muhammad's best friend and early convert to Islam, as his successor, the Shia advocated Ali, Muhammad's cousin and son-in-law. Doctrinal and ritual differences continue to divide the two sects, depending on the locale, education, custom, politics, and personal attitudes of Muslims all over the world.

The aforementioned diversity of perspectives found among 21st-century Muslims was anticipated in the ideas of three early Islamic revivalists who lived in Egypt: Jamal al-Din al-Afghani, Muhammad Abduh, and Muhammad Rashid Rida. These well-known late 19th and early 20th century scholars and activists grappled with questions of modernity, social and political development and relations with the West, and came to different conclusions. Al-Afghani and Abduh, were inclined to meld Western ideas and institutions with Muslim values and society, whereas Rida emphasized Muslim genuineness and encouraged a more conservative, more "fundamentalist" interpretation of what it means to be a Muslim, or Islamic Government. The conservative thought of Rida seems to be strongly influenced Hassan al-Banna, who founded the MB, usually referred to as the Ikhwan, in 1928 in the Ismailia Egyptian city one of the three cities bordering the Suisse Canal.

Nathan J. Brown argued that Egypt's Muslim Brotherhood (MB) social movement has set the pattern for other Islamist movements and many of the various movements it spawned in other countries of the Middle East that continue to refer to the original Egyptian organization as the "mother movement". The MB's unique organizational features of being flexible, with a focused vision, disciplined and engaging, its general emphasis on reform and the effective operation of its informal secret organization (MBSIO), have set the example and tone that other Islamic movements have tried to follow. The MBSIO's informally institutionalized behavior evolved, according to Saad Eddin Ibrahim, from the necessity of survival in the complicated realities of Egyptian politics in the last 84 years - under the monarchy for 24 years and under military dictatorships for 59 years. For all the MB's problems attaining legal status in the last 84 years, the MBSIO still strives to have bylaws, clear criteria for various graduations of membership, regular internal arrangements, established 
procedures for selecting officers, determining policies and positions, collegial and consultative decision making organs, and specialized bodies with clear functions tasks.

Since its establishment by Hassan al-Banna in 1928, the MB movement was used and abused by its members - and also by Islamists who constitute a broad category that includes diverse individuals converging on the goal of creating a sociopolitical, legal and economic order based on interpretations of Islam, not only as a religion, but also as a social and political system.

The MB's entry into political activity in Egypt began early but appeared cautious and almost hesitant at first. In the 1930s, the organization eschewed tight political alliances but still found itself in rivalries among Egyptian political forces (sometimes earning itself a reputation for being close to the palace or to a political party). In addition to forming political alignments, MB's leader Hassan al-Banna focused on a few specifically Islamist causes that had salient political overtones such as: Christian missionary activities, British imperialism, and the brewing conflict between Arabs and Jews in Palestine.

From 1923 to 1952, the MB was perceived by the capitalists liberal ruling elite (during the monarchy time), as part of the Egyptian political landscape. It played an important role in the struggle against the British and the Zionists in Palestine. During the 1940s (particularly during and after WWII's complicated events), the MB got caught several times in the power struggle between King Farouk, the British ambassador (the De Facto ruler of Egypt), and other political parties. The MB was outlawed and its activities were suspended when their MBSIO’s militia assassinated the prime minister of Egypt, Mahmud Fahmy al-Nokrashy (1946). After the 1952 revolution and two years of a honeymoon between the MB and the free officer's corp (who ousted King Farouk), leaders of the MB got caught in the power struggle between Nasser, supported by the majority of the free officers, and General Mohamed Naguib, the figure head of the July 1952 revolution that ousted the Egyptian monarchy. Naguib had favored the restoration of Egypt's parliamentary democracy; Nasser favored a continuing populist revolution under the supervision of the military. The MB was in the middle of these power struggles and they planned and implemented the unsuccessful assassination attempt on Nasser's life in 1954. But Nasser refuted the above arguments in a public televised speech in 1965, arguing that the MB wanted to control political power to build an Islamic state where the Holy Quran would replace the constitution, Islamic jurisprudence would be the law of the land, women ought to wear haijab and stay at home to raise children, all entertainment outlets such as movies and theaters should be abandoned, and the abundance of all western institutions such as political organizations.

Furthermore, Nasser revealed to the public that while the free officers were negotiating with the British to end their occupation of Egypt, leaders of the MB were doing secret negotiations with the British government to allow them (the British) to continue having permanent military basis in the Swiss Canal Zone. The bargain consideration was to enable the MB to be in power. Consequently, the MB was outlawed by the Revolutionary Command Council (RCC) — the Governing Council of the Egyptian revolution and considered to be a threat to Egypt's national security. MB leaders and a large number of members were tried, executed or jailed for a long time without a fair trial in some cases.

In describing the relationship between the Egyptian military and the MB, Goldschmidt noted that,

the 1952 revolution had been a classic army coup, not a popular uprising. If the free officers wanted to gain and hold the people's support, they had to appeal to groups and/or social movements that have wide popular support at the grass roots level, even if these groups or social movements have different views of the free officers' corps. 
The MB satisfied these attributes and the free officers cooperated with them to strengthen the RCC's power over the entire Egyptian state. Nasser tolerated MB, but once the RCC was clearly in control of the government, it could no longer share power with its rivals, among them the MB, old regime politicians, communists, trade unions, Al-Wafd party and other political parties and social movements operating in Egyptian politics. Even though the MB had been outlawed, its secret informal underground organization (MBSIO) continued to operate through person to person contacts in every Egyptian village and city, using forums that could support their activities and incubate it far from Nasser’s security apparatus.

\section{Sadat's Regime as an Opportunity for the MB}

The growing power of political Islam in the last 40 years with its defining features of Egyptian society goes back to the early 1970's when President Sadat of Egypt (1971-1981) used the MB and other Islamic movements to advance one of his political goals of gradually moving away from Nasser's socialist ideology. Sadat unleashed Egypt's Islamic forces including the MB when he released thousands of the MB's leaders and members from jail, and allowed the MB's old newspaper the Call (Al-Dawaa) to be reissued. He encouraged them further by trying to assume the mantle of Islam, calling himself "the guardian of the faith". Also, he emphasized that his first name was "Mohamed," not "Anwar." He promoted religious schools by authorizing a major increase in the budget of Al-Azhar University and the expansion of its parallel education system. Sadat also, opened the door for leading religious commentators to dominate the state-controlled media. Furthermore, he introduced apostasy laws in Egypt after years of a highly liberal intellectual atmosphere, and declared sharia law (Islamic jurisprudence) as the principle source for the Egyptian constitution and declared himself the leader of "an Islamic pious country." In less than a decade, the Egyptian state became quasi-Islamic, replacing the civic secular nature of the 1950s and 1960s under Nasser. To consolidate his power, Sadat felt that Islamic groups including the MB would counterbalance the combined opposition to his regime mounted by Nasserite and leftist elements.

Despite the fact that the MB was allowed to operate tacitly during the Sadat regime, other Islamic movements such as the Sufi, the retreats movement, the Salafist, Repentance and Holy Fight (RHF), and the Islamic Liberation Organization (ISO) - none of them were able to acquire a legal status or license through the Ministry of Social Affairs. The MBSIO was able to operate more freely in the informal realm, than any other Islamist organization in Egypt during Sadat's regime due to the successful social services it provided to the poor population in the urban and rural areas.

During this period, the MB vision of political Islam emphasized two operational principles—one strategic and one tactical. The strategic principle is an assertion of its longstanding call for the establishment of an Islamic social order on the basis of the Shari'a. The tactical principle is the assertion that the MB is seeking its strategic objective in Egypt nonviolently through consciousness raising of the Muslim masses and advice to "Muslim” rulers. The MB's leadership has detached itself from the use of violence against the government through public statements in their publications, and their Mosques during the Friday Prayer. Sadat was assassinated in 1981 by members of al-Jihad who had seemingly split with the Brotherhood, but continued to operate as a part of the MBSIO and resented Sadat's Open Economic policies, as well as the 1979 peace treaty with Israel.

\section{Mubarak’s Regime Co-existence With the MB}

The MB considered the regime Mubarak inherited from Sadat "stultifying, corrupt, and oppressive," 
scholar Nathan Brown wrote. He said the group reconciled its ongoing commitment to Qutb's principles with its renunciation of violence by focusing on the concept of a "vanguard," in which the group seeks to Islamize society "through a [political] elite" as much as it does "through mass work and engagement." From now on—during Mubarak era, the MB became ubiquitous in society, building allegiance as a populist alternative to the Egyptian state, which provided neither prosperity nor welfare, and suffered repeated military defeats by Israel. MB-affiliated candidates first participated in local and parliamentary elections as independents in 1984. Within the Brotherhood, members vary in the orthodoxy of their interpretations of Islam, as well as their ideological versus pragmatic inclinations, but the conservative and insular old guard has dominated in during the 1980s, 1990s to the January 25, 2011 revolutionary wave.

\section{The Impact of the MB's Failure to Govern}

Following Mubarak's removal from office amid mass protests after the January 25, 2010 revolutionary wave, the MB emerged as a dominant political force in Egypt. As of February 2011 the MB hijacked the leaderless revolutionary wave in part because its organizational capacity was unmatched, but the group's victories were tarnished by power struggles with the judiciary and the military. Battles over the drafting of a new constitution were a particular vulgar point. In winter 2011-2012 parliamentary elections, the Brotherhood's Freedom and Justice Party (FJP) won early half the seats in the lower house (People's Assembly), and Islamists took $84 \%$ of the seats in the upper house (Shura Council). Pushing back against the MB's increasing power, in June 2012 the Mubarak-appointed Supreme Constitutional Court dissolved the People's Assembly and revoked a law that would have barred former regime officials from holding office, allowing Mubarak-era prime minister Ahmed Shafiq to run and compete for the presidency. Following a first round of voting in May, 2012, MB's candidate Mohamed Morsi won a narrow majority (51.7\%), in a June, 2012 runoff against Shafiq.

After his election, Morsi ordered the Supreme Military Council of the Armed Forces, which had been acting as an interim government, to its barracks, a move welcomed by much of the officer corps, which was conscious of growing public resentment during its nearly one-and-a-half years at Egypt's power.

Though the 2012 constitution was approved with a 64\% majority in a nationwide referendum, just a third of the electorate voted in the December, 2012 referendum. Opponents were concerned about the role of Islam as the basis of law, feared insufficient protections for women's rights and freedoms of speech and worship, and distrusted the broad power accorded to the presidency.

The conflict between Morsi and the judiciary continued in March 2013 when the Supreme Administrative Court overturned a presidential decree calling for April, 2013 parliamentary elections, questioning the constitutionality of election law provisions. The secular opposition had handed. Middle East expert Robin Wright referred to his style of governing as "majoritarianism," meaning "autocratic rule by the largest party." Opposition to Morsi's rule came to a head in June 2013 with his appointment of 17 brotherhood-affiliated provincial governors, including a member of the former militant group Gamaa Islamiya as governor of Luxor, where the group massacred dozens of tourists in 1997.

Following a new round of mass protests in June 30, 2013, the army, then led by General Abdel Fattah al-Sisi, ousted Morsi on July 3, 2013, and suspended the new constitution. A fifty-member committee that convened to amend the constitution included just two Islamists, neither of whom represented the MB. Egyptians voted and approved the new constitution on January 14 and 15, 2014. The revised document keeps much of the 2012 text, but tempers references to Islam as the basis of Egyptian law and bolsters the authority 
and autonomy of the military, the security-police and judiciary. It also restores the 1971 constitution's ban on political parties with a religious foundation or reference, which bared the FJP from electoral politics.

The failure of MB's - (the mother organization of all social and political movements of the 20th century) to govern in Egypt can be considered a set back to the revival of Islam as a political force in the Middle East, the Islamic World and IR generally. Also, as a lost opportunity to the reestablishment of the Islamic nation—Omaha—ruled by a Kalifah, executing Sharia on his subjects.

\section{Political Islam and IR}

To many Muslims, the sense of injustice in IR is symbolized by the fate of the Palestinian people, especially the perceived Western-led by the United States use of double standards. Strictly upholding resolutions and international law when it comes to Muslim countries, but not when it involves Israel, is something of which all Muslims are sharply aware. Chris Patten, while serving as the EU Commissioner of External Relations, stated that "the treatment of Palestinians" is one of the major areas of policy where the approach we in America and Europe could abate or exacerbate Arab hostility, and build rather than burn bridges between the West and the whole of the Islamic World.

Muslims feel a similar Western use of double standards when it comes to democracy. Many Muslim countries and all Arab countries ruled by authoritarian dictatorships (whether monarchies or republican forms of governments) lack democratic systems. These regimes are being supported by the West (including the United States) due to the later economic or other regional strategic interests—ranging from securing the flow of oil to the west, arms selling, and to the survival of Israel-the Arab and Muslims common enemy.

\section{The Limitation of Existing IR Theories}

The terrorist attack of September 11, 2001 on the United States has proved the inability of any IR theory in the era of globalization to predict threats of such a magnitude. Likewise, the tragic Charlie Hebdo event in Paris, in September 2015, and the recent March 22, 2016 Brussels events where Islamic State blasts killed 31, confirmed the threat posed by political Islam and its ability of imposing its existence as a player in international politics theater and IR. Western IR's theories, explanatory powers, predictability's range, or probability of minimizing risks of interstate or intrastate threats caused by Islamic Jihadists proved its limitations in dealing with the current events in the Middle East, Europe and the United States after the recent Orlando, Florida massacre of June 12, 2016 where 50 killed at gay club.

The post-World War IR theories, which provided the basis of the military, security, and intelligence Agencies' doctrines and operational strategies and tactics proved its lack of reliability and validity. The terrorist assault on Brussels, just four days after the arrest of an architect of last year's attacks on Paris, underlined the resilience and continued menace of political Islam and the Islamic state- to Europe, to the United States and their vital Western interests in the Middle East and Islamic World. The aforementioned event was coupled with the surprise and shock of scholars, policy makers, and the general public in the West in response to the attacks, signaled that something was amiss in the way that IR's scholars approached global politics in general and the question of religion in particular.

Erin Wilson, the Director of the Center for Religion, Conflict, and Public Domain (CRCPD) of the Groningen University in the Netherland, summarized eloquently the scholarly reactions to the aforementioned events that, 
it has been mixed, with some arguing that the world changed irrevocably, while others claimed the world was no different. Perhaps one of the most enduring effects of the attacks has been the questions raised about the role of religion in society and politics. What these tragic events emphasized, possibly more than any other event in recent history, was that religion continues to be a powerful force not only in domestic politics but also in global politics, yet one whose influence is only partially understood by scholars and practitioners alike. Since then, there has been growing recognition amongst IR scholars of the existence of a "secularist bias" within the field (and, arguably, in public and political discourses within the West more generally. This bias in many ways explains why, for much of the history of IR, scholars failed to even consider the place of religion within global politics. Other more recent works have emphasized how this bias contributes to inaccurate and incomplete understandings of the role religion plays in a variety of political contexts, including in the so-called secular west. These critiques have highlighted important shortcomings of the secularist model of analysis dominant within IR and have contributed to expanding approaches to the question of religion and its influence on politics. Yet despite their significant contribution to the study of religion in IR, problems persist among the majority of efforts to critique secularism and engage with the question of religion and politics. Many of these shortcomings stem from the fact that, until the last decade or so, most attempts to discuss religion within IR paid little attention to the role of religion in the politics of Western states and its impact on their policies and actions in global politics. Given the dominance of a number of Western states in global politics, coupled with the historical emergence of the international states-system out of the European states-system. Ignoring or overlooking religion in the politics of Western states questionably hindered efforts to understand the role of religion-particularly Islam in the Muslim world including the Middle East, and IR and global politics more generally.

Hence, efforts to explore the role of religion in Western and Islamic countries politics are needed particularly now where ISIS's appeal spreads globally. Massacres attributed to the Islamic State have struck on four continents this year of 2016, reflecting how the appeal of the group's ideology is growing even as the territory it controls in Iraq and Syria has receded according to experts.

\section{Prospects for the Middle East Stability}

The Arab Spring collapsed rotten autocratic regimes in the Middle East such as Zeen Al-Aberdeen Ali of Tunisia, Hosni Mubarak of Egypt, Moamar Al-Gadhafi of Libya, and Abdulla Saleh of Yemen, but with the exception of Tunisia, democratic forces are not ready to fill the vacuum. The results were civil wars (as in Libya, Syria, and Yemen) or restored dictatorships such as in Egypt. The current shape of the Middle East is likely to be going in both directions at once towards stability and instability. This means that the international mitigating efforts through the diplomacy of the United States and members of the European Union such as Germany, England, France, Italy, and the United Nations towards stabilization is being cancelled by other opposing forces in the Middle East regions such as the Russian intervention in Syria, the complicated regional realities and rivalry between Saudi Arabia, the Gulf States and Iran. And the continued support of Turkey and Qatar (both close allies to the United States) to the MB international organization, despite being classified by the Egyptian government-based on court's ruling as a terrorist organization.

Recently the House Judiciary Committee under the leadership of Congressman Diaz-Balart passed H.R. 3892, also, designated the Muslim Brotherhood as a Terrorist Organization (Designation Act of 2015), by a vote of 17-10. The aforementioned law was followed by Senator Ted Cruz (R-TX), who introduced a companion bill in the Senate. The bill would call on the State Department to "recognize and sanction the Muslim Brotherhood as a foreign terrorist organization”. He argued that,

the MB's jihadist movement is actively supporting and financing terrorist networks around the world, including al-Qaeda and Hamas. Hence, the United States must recognize and sanction the MB as a terrorist organization as part of the U.S. national security strategy. 
The remains of the Middle East mixture are as sharp and dangerous as ever, but U.S. role is significant. No other nation can match the power of the United States in advancing liberal values. In doing so, the United States should be more careful when conducting its IR with the Muslims states where the Mosque still and will continue to be meshed (interwoven) with the state. Also, applying one standard of fairness based on international law and the American Founding Fathers good values of liberty, justice, and pursuit of happiness to the Arab/Muslim-Israeli conflict will gradually alleviate the Muslims lack of confidence and mistrust of the United States while playing its mediating role in the Arab/Muslim Israeli protracted political conflict.

The past decade in U.S. foreign policy has been marked by crises of confidence, a feeling of fatigue and withdrawal from IR imposed by domestic economic issues. Those who hope for a resurgence of freedom around the world generally and stability in the Middle East, can only hope that American voters, in this year of 2016’s Presidential election would elect a President who will revive U.S. democratic leadership at the World stage.

\section{References}

Arthur, G. Jr. (2008). A brief history of Egypt. New York: Checkmark Books.

Berger, M. (2010). Religion and Islam in contemporary international relations. The Hague Netherlands Institute of International Relations, Clingendael Diplomacy Papers, 27, 4.

Brown, N. J. (2012). When victory is not an option, Islamist movements in Arab politics. Ithaca: Cornel University Press.

Editorial (2016). Democracy in retreat, illiberal regimes are on the March, the U.S. must pay attention. Washington Post, March 14, 2016, A16.

Feldman, N. (2007). The fall and rise of the Islamic State, a council on foreign relations book. New Jersey: Princeton University Press.

Frieden, J. A., Lake, D. A., \& Schultz, K. A. (2016). World politics, interests, interactions, institutions. New York: W. W. Norton \& Company.

Goldman, A., Warrick, J., \& Bearak, M. (2016). 50 killed at Gay Club in Florida. Washington Post, June 12, $2016,1$.

Hala, M. (2015). America, the brotherhood and the beginning of division. Retrieved June 20, 2015, from http://www.alahram.org.eg/News Print/406909.aspx

Ibrahim, S. E. (1996). Egypt, Islam, and democracy, twelve critical essays. Cairo: The American University in Cairo Press.

Ignatius, D. (2016). The jagged Middle East Puzzle. Washington Post, March 2, 2016, A25.

Kissinger, H. (1994). Diplomacy. New York: Simon \& Schuster.

Laub, Z. (2014). Online writer/editor, Egypt's Muslim brotherhood. Council on Foreign Relations, 1(15). Washington, DC, Updated.

Morello, C., \& Warrick, J. (2016). ISIS’s appeal spreads globally-attacks this year on 4 continents. Washington Post, July 4, 2016, 1.

Morone, J. A., \& Kersh, R. (2014). By the people, debating American government. Oxford: Oxford University Press.

Norton, A. R. (2002). Activism and reform in Islam. Current History, A Journal of Contemporary World Affairs, 101(658), 377.

Sachedina, A. (2001). The Islamic roots of democratic pluralism. Oxford: Oxford University Press.

Sherif, A. E. (2011). Islamism after the Arab Spring. Current History, a Journal of Contemporary World Affairs, 110(740), 359.

Sly, L., \& Morris, L. (2014). Militants making headway in Iraq and Syria declare creation of formal Islamic State. Washington Post, 6, 30, A6.

Springborg, S., \& Clement, M. H. (2011). Army guys. The American Interest, VI(5) (May/June 2011), 16.

Vatikiotis, P. J. (1991). The history of modern Egypt, from Muhammad Ali to Mubarak. Baltimore: The Johns Hopkins University Press.

Wilson, E. (2013). Religion and international relations theory. (NGIZ Nord and the Center for Religion, Conflict and The Public Domain-Faculty of Theology and Religious Studies, Co-hosted an evening devoted to a discussion of the dominant approaches to religion in the study of International Relations Groningen University, Netherland, November, 28, 2013). 